\title{
Improving the topology of CAD models in the context of their susceptibility to design changes - model preparation stage. Part 1
}

\author{
Doskonalenie topologii modeli CAD w kontekście ich podatności \\ na zmiany konstrukcyjne - etap przygotowania modelu. Część 1
}

\section{GRZEGORZ ŚWIACZNY MAREK WYLEŻOŁ*}

DOI: https://doi.org/10.17814/mechanik.2020.8-9.16

\begin{abstract}
The article presents the importance of effective use of CAx class systems in the design of elements made of plastic. An example of the process of creating such an element - a rear car reflex lamp - is described. The $1^{\text {st }}$ part of the article focuses on showing the individual phases of preparing a 3D model of the reflex lamp, while the $2^{\text {nd }}$ part will present the process of its modification. The authors pay special attention to the role of the tree of the 3D model structure, which is a key factor influencing the project timing. KEYWORDS: topology of CAD model, injection technology, plastics, automotive industry, CATIA v5
\end{abstract}

Przedstawiono wagę efektywnego wykorzystania systemów klasy CAx podczas projektowania elementów z tworzywa sztucznego. Opisano proces tworzenia takiego elementu - na przykładzie tylnego odblasku samochodowego. Część 1 artykułu koncentruje się na pokazaniu poszczególnych faz przygotowania modelu 3D odblasku, natomiast w części 2 zostanie opisany proces jego modyfikacji. Autorzy zwracają uwagę na rolę drzewa struktury modelu 3D, będącego kluczowym czynnikiem wpływającym na czas realizacji projektu.

SŁOWA KLUCZOWE: topologia modelu CAD, technologia wtrysku, tworzywa sztuczne, przemysł samochodowy, CATIA v5

\section{Wprowadzenie}

Systemy klasy CAx na dobre zagościły w przemyśle. I choć ich popularność nikogo już nie dziwi, to wiedza na temat ich efektywnego wykorzystania i ról, jakie pełnią w projektach, w dalszym ciągu nie jest pełna. Autorzy podejmują próbę przybliżenia tych zagadnień na przykładzie wykonywania elementów z tworzywa sztucznego w przemyśle motoryzacyjnym.

Właściwości tworzyw sztucznych - ich podatność na swobodne formowanie $\mathrm{z}$ zachowaniem akceptowalnej masy i wytrzymałości - sprawiły, że wraz z wprowadzeniem systemów klasy CAx stała się możliwa realizacja wielu skomplikowanych pod względem kształtu pomysłów stylistów samochodowych, a granica technologiczności projektu jest nieustannie przesuwana. Proces tworzenia pozostaje jednak czaso- i pracochłonny. Dodatkowo wymaga on dużej wiedzy z wielu dziedzin inżynierii, przede wszystkim materiałoznawstwa, wytrzymałości materiałów, mechaniki i technologii produkcji. Oprócz tego ogromną rolę odgrywa sposób tworzenia wirtualnego modelu 3D w środowisku danego systemu klasy CAx.

Poziom skomplikowania kształtu elementów z tworzywa sztucznego jest czasem tak wielki, że przebieg całego projektu w dużym stopniu zależy od jakości modelu 3D. 0 ile rola ogólnie definiowanego konstruktora zakłada bazowanie na wiedzy z różnych dziedzin inżynierii - mechaniki, obliczeń wytrzymałościowych czy doboru materiałów - o tyle obowiązki konstruktora elementów z tworzywa sztucznego w przemyśle motoryzacyjnym w większości ograniczają się do pracy w systemach klasy CAx i tworzenia struktury modelu 3D. W dalszej części artykułu pojęcie „konstruktor" i związane z nim terminy będą się odnosić do tej właśnie roli.

Proces tworzenia wirtualnego modelu w środowisku CAx jest długi, jednak - paradoksalnie - poświęcenie większej ilości czasu na optymalizację jego konstrukcji skraca cały proces. Wynika to z tego, że topologia modelu 3D musi uwzględniać potrzebę wielokrotnego wprowadzania modyfikacji zgodnie z wymaganiami klienta oraz technologicznością produktu. Optymalnie utworzony model nie może stanowić bariery do implementowania zmian i pozwala na zrealizowanie projektu w założonym czasie. Dodatkowo może on stanowić bazę do kolejnych projektów, co sprzyja zachowaniu terminowości, a co za tym idzie oszczędności kosztów i zadowoleniu klienta.

Aby jednak do tego doszło, konstruktor musi przejść przez wiele etapów, podczas których wielokrotnie przebudowuje strukturę modelu, aby uzyskać pożądany efekt z zachowaniem pełnej modyfikowalności. Swego rodzaju burza mózgów jest nieodłącznym stanem umysłu konstruktora, który w jak najkrótszym czasie proponuje i wprowadza wiele różnych rozwiązań danego zagadnienia konstrukcyjnego. Od jego wiedzy i doświadczenia zależy, jak szybko i czy w ogóle znajdzie optymalne rozwiązanie wobec uświadomionych lub narzuconych mu kryteriów.

\footnotetext{
* Mgr inż. Grzegorz Świaczny, grzegorz.swiaczny@gmail.com, Polska

Dr hab. inż. Marek Wyleżoł, prof. PŚ, marek.wylezol@polsl.pl, https://orcid.org/0000-0001-6324-510X - Politechnika Śląska, Gliwice, Polska
} 


\section{Proces projektowania tylnego odblasku samochodowego}

Znaczenie efektywnego wykorzystania systemów klasy CAx zostanie pokazane na przykładzie procesu projektowania elementu tylnego zderzaka samochodowego - odblasku (rys. 1). Odblask ten składa się z soczewki zewnętrznej, obudowy oraz gore-texowej membrany (rys. 2).

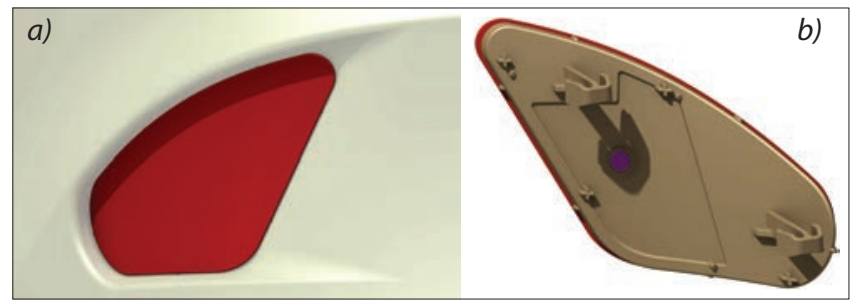

Fig. 1. Rear car reflex lamp: $a$ ) reflex lamp with a bumper - view from the rear of the car, $b$ ) view from the rear of the reflex lamp Rys. 1. Tylny odblask samochodowy: $a$ ) odblask ze zderzakiem - widok od tyłu samochodu, $b$ ) widok od tyłu odblasku

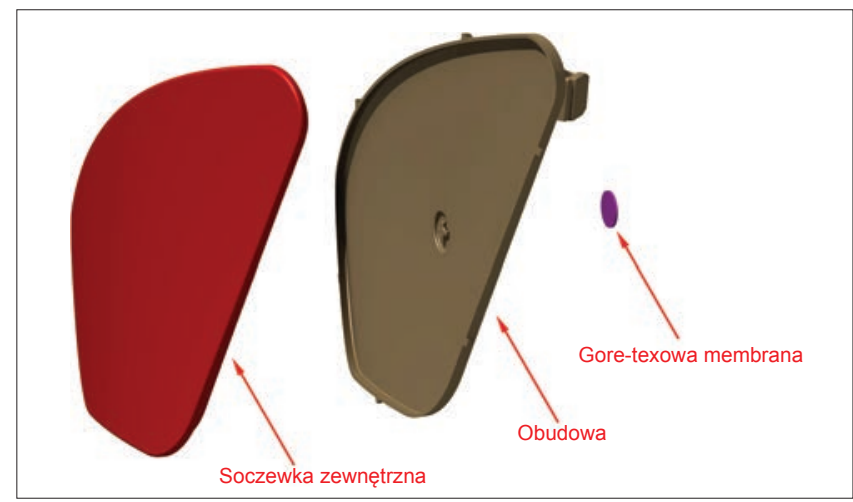

Fig. 2. Rear car reflex lamp - explosive view

Rys. 2. Tylny odblask samochodowy - widok eksplozyjny

Soczewka zewnętrzna i obudowa docelowo będą wytwarzane w technologii wtrysku, która jest podstawowym procesem wytwarzania z tworzyw sztucznych gotowych wyrobów o masie od 0,01 g do $70 \mathrm{~kg}$; od cześci dla mikroniki do pojemników transportowych i kabin telefonicznych [1]. Oznacza to, że podczas procesu projektowania kluczowe z punktu widzenia technologii wytwarzania będą takie aspekty, jak:

- Dobór głównej płaszczyzny podziału formy i dodatkowych płaszczyzn podziału dla segmentów formujących (zwanych dalej liniami podziału formy). Elementy wytwarzane $\mathrm{w}$ technologii wtrysku powstają $\mathrm{w}$ procesie wtryskiwania wcześniej uplastycznionego tworzywa do formy, w której ulega ono zestaleniu i skąd zostaje usunięte w postaci tzw. wypraski.

Typowa forma wtryskowa składa się z dwóch połówek (części): nieruchomej, zwanej również prawq lub wtryskowa, zwiazanej z nieruchomym stołem wtryskarki; ruchomej, zwanej także lewą lub wypychaczowa, zwiqzanej z ruchomym stołem wtryskarki [2].

Przestrzeń wewnątrz formy, którą zajmuje uplastycznione tworzywo, nosi nazwę gniazda formującego. Zatem gniazdo formujące jest wynikiem zamknięcia dwóch połówek formy, przy czym obszar jednej po- łówki formy nosi nazwę matrycy, a obszar drugiej potówki formy - stempla.

Aby wyjąć wypraskę z gniazda formującego, trzeba je podzielić wzdłuż płaszczyzny zwanej płaszczyzną podziału. Płaszczyzna ta zostawia na wyprasce ślad - linię podziału [2].

Podczas konstruowania modelu 3D, będącego geometryczną postacią fizycznej wypraski, konstruktor ma wpływ na płaszczyznę podziału formy wtryskowej i na dodatkowe płaszczyzny podziału dla ewentualnych segmentów formujących (tzw. suwaków). Musi je uwzględnić $w$ postaci linii podziału formy/suwaków w modelu 3D.

- Dobór kierunku usuwania stempla z matrycy formy (otwierania formy) i dodatkowych kierunków dla segmentów formujących (suwaków). Przyjmuje się, że matryca to wklęsła część gniazda, a stempel wypukła. Jednakże w wielu przypadkach, z racji uwypuklajacej się obustronnie wypraski, określenie to nie jest jednoznaczne. $W$ takich formach stemplem nazywa sie część o przewadze fragmentów wypukłych lub też część płaską wspótpracująca z częściq wklęsłą albo też (przy dalszych wątpliwościach) część gniazda zaopatrzona $w$ wypychacze (elementy wypychające wypraskę po zakończeniu procesu wtrysku i otwarciu formy) [2].

Aby model 3D reprezentował technologiczną postać wypraski, musi być skonstruowany na bazie jednej $\mathrm{z}$ podstawowych cech charakteryzujących budowę formy - kierunku, w którym stempel będzie usuwany z matrycy podczas otwierania formy po zakończeniu wtrysku. Kierunek ten, podobnie jak kierunki ewentualnych segmentów formujących (suwaków), wybiera konstruktor modelu 3D wypraski.

- Dobór rodzaju tworzywa sztucznego. $W$ wyniku wtrysku uzyskuje się wypraskę charakteryzujaca sie nie tylko określonym kształtem, lecz także specyficznq struktura wynikającq ze sposobu płynięcia stopu $w$ formie oraz przebiegu jego krzepnięcia [2].

Dobór rodzaju tworzywa determinuje m.in. optymalną grubość ścian modelu 3D czy wartość pochylenia ścian - co konstruktor musi mieć na uwadze.

- Utrzymanie stałej grubości ścian elementu. Obowiq̨zuje ogólna zasada zachowania możliwie równomiernej grubości ścian wypraski (modelu 3D) dla uniknięcia jam skurczowych, wciagów i naprężeń wewnętrznych [2].

- Dobór optymalnej wartości kątowej pochylenia ścian bocznych elementu. Aby ułatwić otwarcie formy i wyjęcie wypraski, a w większości przypadków aby to w ogóle było możliwe - konieczne jest pochylenie ścian bocznych w kierunku usuwania z matrycy stempla i ewentualnych segmentów formujących. Dzięki temu pochyleniu już po niewielkim przesunięciu wypraski względem elementu formującego powstaje między nimi luz i znika niebezpieczeństwo zatarcia, zniekształcenia czy nawet zniszczenia wypraski [2].

W gestii konstruktora jest zapewnienie, aby utworzony model 3D miał optymalne wartości pochylenia ścian, a także aby nie zawierał rejonów z pochyleniami ujemnymi - tzw. podcięć - w kierunku usuwania z matrycy stempla lub segmentów formujących (suwaków). 
Oczywiście ze względu na technologię wtrysku konstruktor musi zwracać uwagę na wiele innych aspektów, które jednak dla poruszanego tematu nie są istotne i zostaną pominięte. Dodatkowo w procesie wytwarzania użyta zostanie technologia zgrzewania wibracyjnego, aby połączyć soczewkę zewnętrzną $\mathrm{z}$ obudową, a co za tym idzie - zapewnić wymaganą szczelność docelowego elementu. Zgrzewanie wibracyjne (VIB) należy do metod łączenia tworzyw sztucznych, w których ciepło niezbędne do procesu łączenia uzyskuje się na skutek tarcia [3].

Na pierwszym etapie projektowania zespół projektowy otrzymuje od odbiorcy szczegółową dokumentację dotyczącą każdego aspektu organizacyjnego, prawnego i funkcjonalnego docelowego elementu, poczynając od celów rynkowych (rynek europejski, amerykański, chiński itd.), numerów produkcyjnych, poprzez wymagania geometryczne i tolerancji, a kończąc na sposobie dostarczania danych 3D/2D oraz gotowych wyrobów. Dla konstruktora najistotniejsze są informacje techniczne bezpośrednio związane $\mathrm{z}$ projektowanym elementem oraz geometryczne dane wejściowe $\mathrm{w}$ postaci powierzchniowych modeli 3D jednoznacznie opisujących wygląd zewnętrzny przyszłego wyrobu i innych elementów bezpośrednio z nim związanych. Modele powierzchniowe (zwane dalej powierzchniami $A$ ), zapisane w formacie kompatybilnym z systemem klasy CAx, są jednocześnie bazą, na podstawie której konstruktor rozpoczyna tworzenie nowych modeli 3D. W rozpatrywanym przykładzie pierwszą geometryczną daną wejściową jest powierzchnia $A$ soczewki zewnętrznej odblasku (rys. 3).

Drugą daną wejściową są elementy otoczenia, z którymi rozpatrywany element będzie współpracował. W tym przypadku będzie to powierzchnia $A$ tylnego zderzaka, do którego odblask będzie montowany (rys. 4).

Należy zaznaczyć, że konstruktor nie może modyfikować żadnych danych wejściowych - powierzchni $A$ soczewki i powierzchni $A$ zderzaka - bez konsultacji z bezpośrednim odbiorcą. Bardzo rzadko się zdarza, aby odbiorca pozwolił na zmianę powierzchni zewnętrznej. W zasadzie jedyny przypadek, gdy

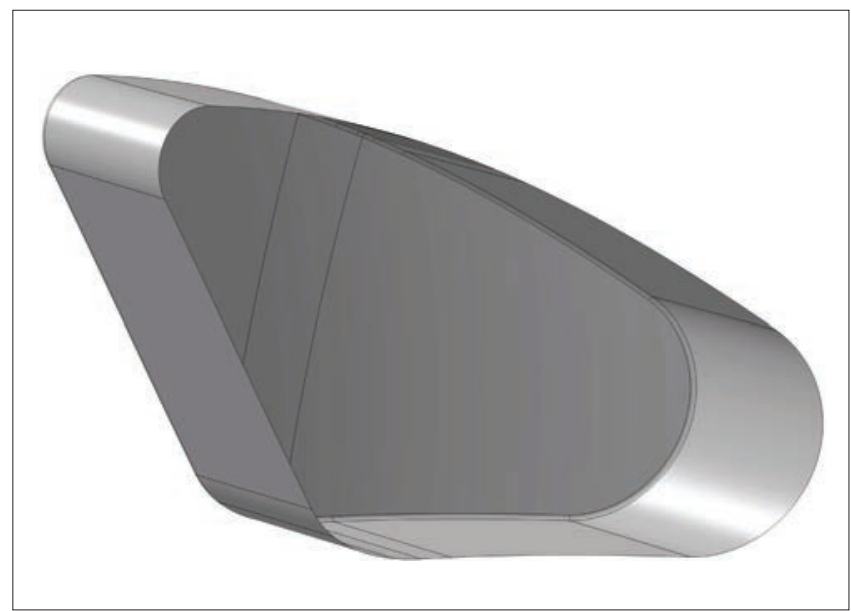

Fig. 3. Outer surface of the reflex lamp ( $A$ surface of the lens) Rys. 3. Powierzchnia zewnętrzna odblasku (powierzchnia $A$ soczewki)

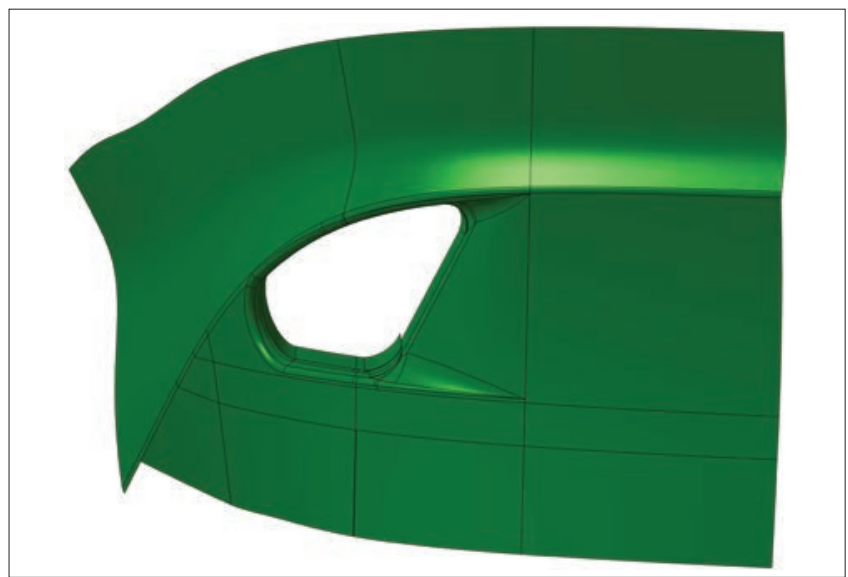

Fig. 4. The outer surface of the car rear bumper ( $A$ surface of the bumper)

Rys. 4. Zewnętrzna powierzchnia tylnego zderzaka samochodu (powierzchnia A zderzaka)

konstruktor może ingerować $\mathrm{w}$ wejściowe cechy geometryczne, dotyczy sytuacji, w której cechy te są technologicznie niewykonalne, a co za tym idzie - istnieje ryzyko (a właściwie pewność), że element docelowy nie będzie możliwy do wytworzenia. Wówczas obowiązkiem konstruktora jest niezwłoczne poinformowanie o tym odbiorcy. Odbiorca decyduje, czy poprawić zgłoszony błąd samodzielnie, czy zlecić konstruktorowi zaproponowanie wykonalnego rozwiązania.

Aby ograniczyć ryzyko implementacji błędnych wejściowych cech geometrycznych, konstruktor na pierwszym etapie tworzenia modelu 3D przystępuje do analizy otrzymanych danych pod kątem wykonalności. Pomaga mu $\mathrm{w}$ tym narzędzie wbudowane w system klasy CAx - Analiza Pochyleń Ścian. Pozwala ono jednoznacznie ocenić, czy ilościowe wartości opisujące cechy geometryczne modeli 3D są, pod kątem pochylenia ścian, wykonalne $\mathrm{w}$ wybranej technologii wytwarzania elementu (rys. 5).

Analiza pochyleń omawianego odblasku tylnego wykazała, że powierzchnia $A$ soczewki i powierzchnia $A$ zderzaka są zgodne z przyjętym głównym kierunkiem otwierania formy. Oznacza to, że konstruktor $\mathrm{w}$ analizowanych powierzchniach nie stwierdził obecności podcięć, a zaproponowane przez odbiorcę wartości pochyleń ścian spełniają wymogi technologii

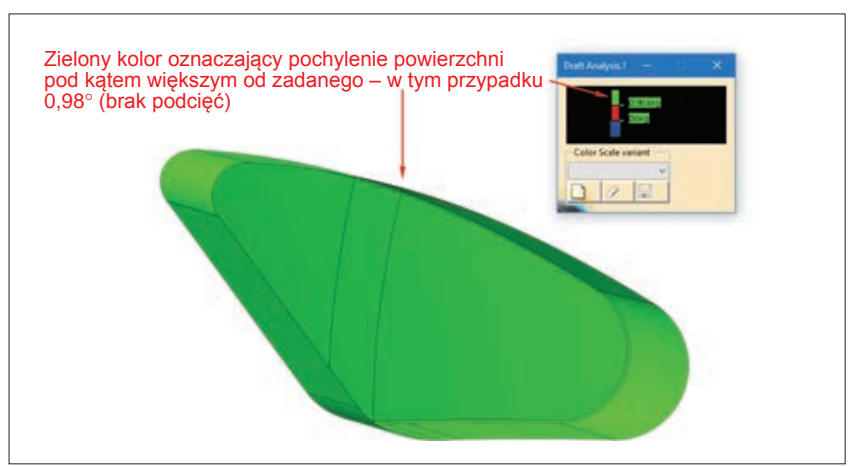

Fig. 5. Draft analysis of $A$ surface using the Wall Draft Analysis function

Rys. 5. Analiza pochyleń powierzchni $A$ z użyciem funkcji Analiza Pochyleń Ścian 
wtrysku oraz pokrywają się ze zdolnością produkcyjną przedsiębiorstwa, w którym odblask będzie wytwarzany. Po analizie konstruktor jest w stanie ocenić, czy wejściowe cechy geometryczne dostarczone przez odbiorcę są - pod kątem pochylenia ścian - wykonalne.

Analiza pochyleń nie jest jedyną analizą, którą należy wykonać na pierwszym etapie projektowania. Na podstawie danych wejściowych konstruktor musi również ocenić inne aspekty, np. zachowanie nominalnej grubości ścian, minimalnej grubości narzędzia (formy) czy - tak jak w tym przypadku - wykonalność zgrzewania wibracyjnego soczewki odblasku $\mathrm{z}$ jego obudową. Istotnymi elementami są też tworzenie pierwszych konceptów mocowań oraz analiza montażu.

Po przeanalizowaniu danych wejściowych konstruktor przystępuje do drugiego etapu projektowania tworzenia grubości elementu - lub inaczej - tworzenia powierzchni $B$ elementu. Jest to o tyle istotne, że dane wejściowe odbiorcy zostają przekształcone z powierzchni w bryłę. Proces ten polega na odsunięciu powierzchni $A$ o nominalną wartość grubości ścianki elementu, a następnie zamknięciu powierzchni $A$ i $B$ odpowiednio przyciętymi powierzchniami bocznymi.

Może się to odbyć na dwa sposoby. Pierwszym, prostszym jest użycie narzędzia, które na podstawie powierzchni $A$ automatycznie tworzy bryłę o zadanej grubości. Wystarczy wskazać zadaną powierzchnię i wpisać w okno edycyjne narzędzia żądaną grubość, a system automatycznie utworzy bryłę, bez konieczności manualnego zamykania odsuniętych od siebie powierzchni odpowiednio przyciętymi powierzchniami bocznymi (rys. 6).

Jednak często automatyczne utworzenie bryły nie jest możliwe. Dzieje się tak, gdy system klasy CAx nie jest w stanie wygenerować wiernego pod względem geometrycznym i matematycznym odsunięcia od powierzchni bazowej. Wówczas konstruktor tworzy powierzchnię $B$ za pomocą narzędzia Odsunięcia. Gdy to narzędzie wykrywa błąd powierzchni bazowej, należy pominąć problematyczny rejon, a następnie w kolejnym kroku „załatać” powstałą nieciągłość. Po utworzeniu powierzchni $B$ tworzone są powierzchnie

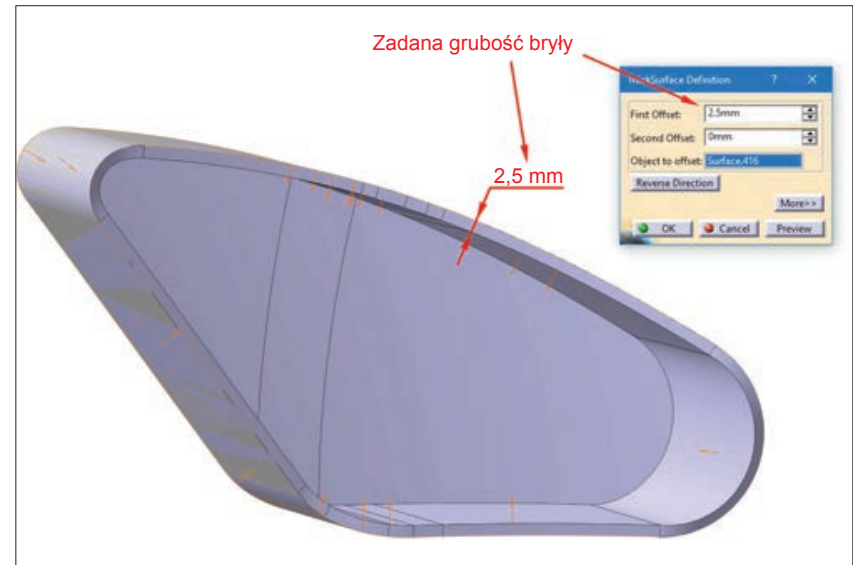

Fig. 6. Automatic solid generation on the basis of $A$ surface of the lens

Rys. 6. Automatyczne generowanie bryły na podstawie powierzchni $A$ soczewki boczne, które po odpowiednim przycięciu tworzą zamkniętą całość z powierzchniami głównymi (rys. 7b). Aby przekształcić taką zamkniętą formę w bryłę, należy skorzystać z kolejnego narzędzia. W niektórych systemach CAx proces ten odbywa się automatycznie.

W przypadku soczewki zewnętrznej oprócz nadania grubości należy dodać żebro wynikające z technologii łączenia jej z obudową (zgrzewania wibracyjnego). Natomiast niezbędnymi składnikami ukończonego modelu 3D elementu wykonanego z tworzywa sztucznego są kierunek usuwania stempla z matrycy (kierunek otwierania formy) i linia podziału formy, które w tym przypadku również zostały dodane (rys. 8).

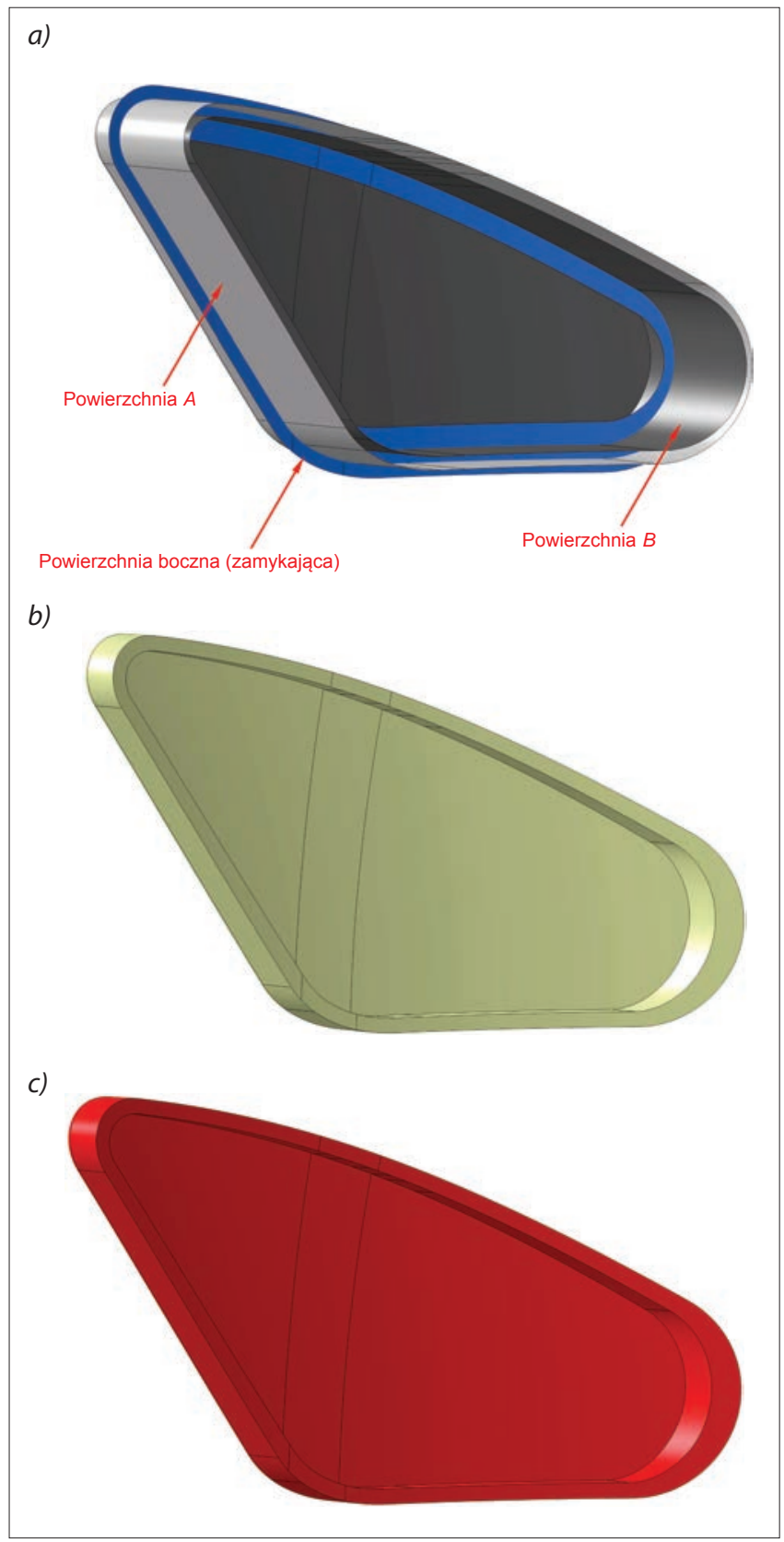

Fig. 7. Creating a solid by preparing $B$ surface and closing surfaces: a) surfaces prepared for trimming, $b$ ) trimmed surfaces forming a closed form, c) ready-made solid formed on the basis of a closed surface

Rys. 7. Tworzenie bryły poprzez przygotowanie powierzchni $B$ i powierzchni zamykających: a) powierzchnie przygotowane do przycinania, b) przycięte powierzchnie tworzące formę zamkniętą, c) gotowa bryła utworzona na podstawie zamkniętej powierzchni 
Kolejny etap projektowania zależy od charakteru danego elementu. W opisywanym przykładzie po utworzeniu soczewki odblasku następuje przygotowanie obudowy. Obudowa odblasku o tyle różni się od soczewki zewnętrznej, że nie jest widoczna z zewnątrz. Konstruktor ma więc pełny wpływ na jej wygląd zewnętrzny oraz oczywiście funkcjonalność, jednak obudowa nie może przybrać dowolnego kształtu. Podstawową daną wejściową w tym przypadku będzie sama soczewka zewnętrza (jej postać geometryczna), która determinuje kształt obudowy. Kolejną daną wejściową są wewnętrzne elementy samochodu składające się na bezpośrednie otoczenie odblasku.

Jak wspomniano, konstruktor powinien dążyć do tego, aby struktura tworzonego modelu 3D była jak najbardziej zoptymalizowana. Oznacza to, że aby utworzyć obudowę omawianego odblasku, należałoby dostarczyć jak najmniej danych wejściowych, które jednak jednoznacznie opisywałyby jej postać geometryczną. Zatem konstruktor rozpoczyna upraszczanie struktury modelu już na etapie doboru jej danych wejściowych.

W tym przypadku do jednoznacznego określenia geometrycznej postaci obudowy wystarczą dwie dane: płat powierzchni $B$ soczewki i płat zewnętrznej powierzchni żebra zgrzewania wibracyjnego. Ważne aby wielkość tych płatów nie ograniczała się do obszaru obudowy. Często się zdarza, że trzeba powiększyć (ekstrapolować) elementy składowe struk-

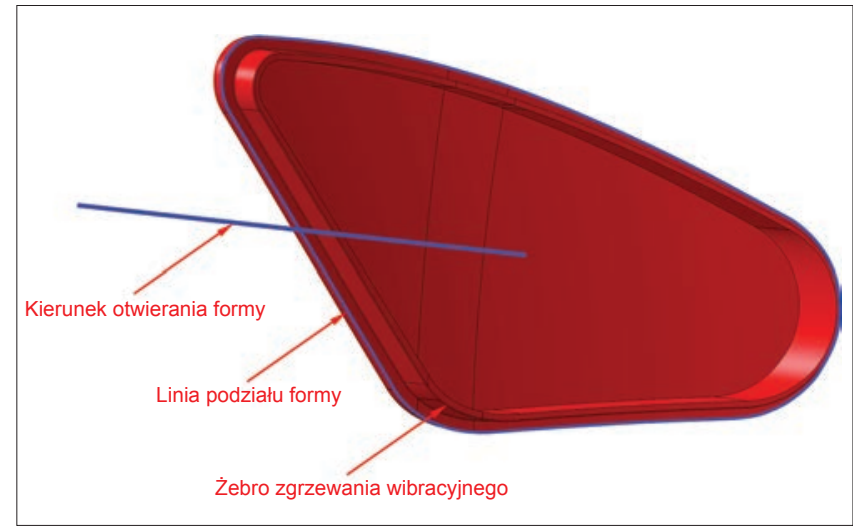

Fig. 8. The finished model of the outer lens

Rys. 8. Ukończony model soczewki zewnętrznej

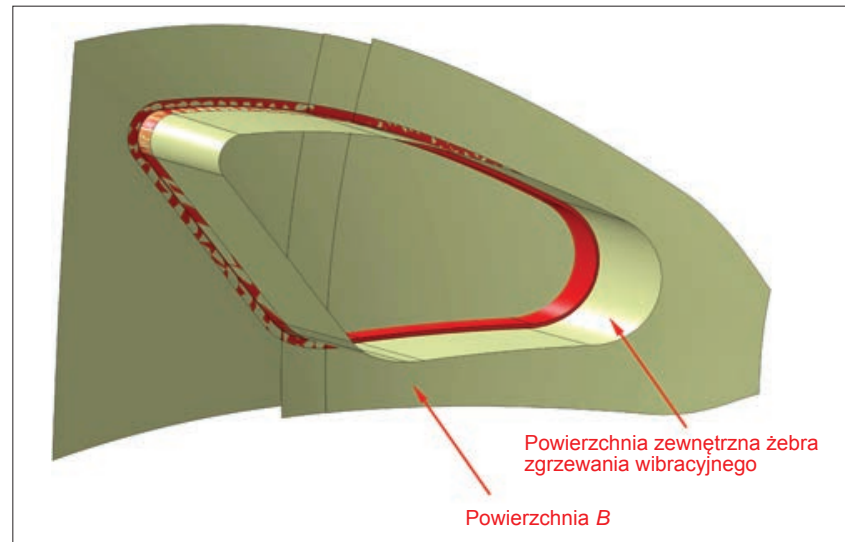

Fig. 9. Surface patches significantly exceeding the geometrical form of the lens, which are the input data of the housing

Rys. 9. Płaty powierzchni znacznie przekraczające postać geometryczną soczewki, będące danymi wejściowymi obudowy tury modelu 3D, aby końcowy rezultat zawarł się w - czasem - znacznie mniejszym obszarze. By uniknąć dodatkowych operacji powiększania płatów powierzchni, należy je utworzyć w modelu źródłowym z myślą o ich przyszłym charakterze. To kolejna faza upraszczania struktury obudowy już na etapie tworzenia soczewki zewnętrznej. Optymalizacja struktury docelowego modelu oznacza pracę na wielopoziomowym wykorzystaniu jego wszystkich składowych. Utworzone płaty powierzchni soczewki znacznie przekraczają obszar samej soczewki, lecz ich wielkość nie służy jej strukturze, a strukturze obudowy, która w momencie tworzenia soczewki jeszcze nie istnieje (rys. 9).

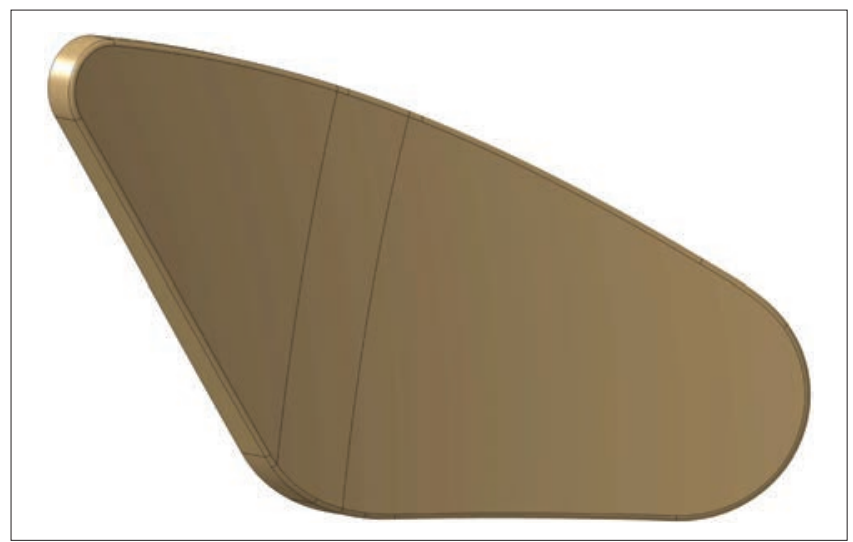

Fig. 10. The basic shape of the housing Rys. 10. Podstawowa bryła obudowy

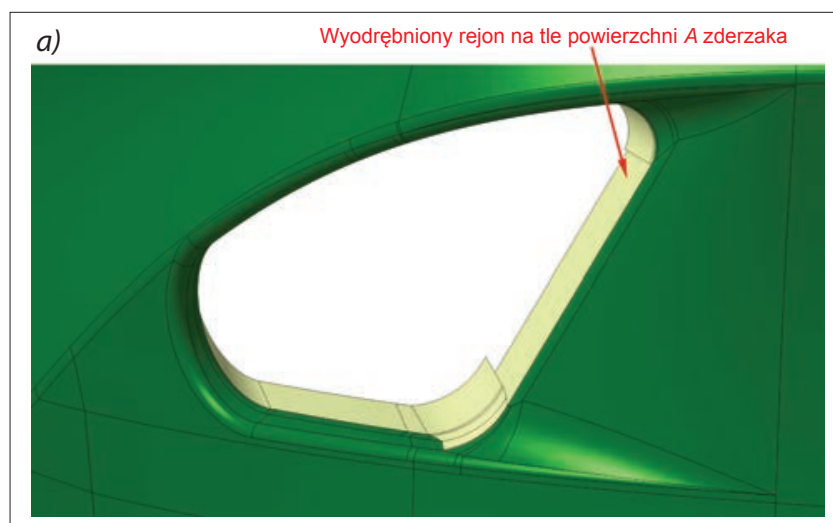

b)

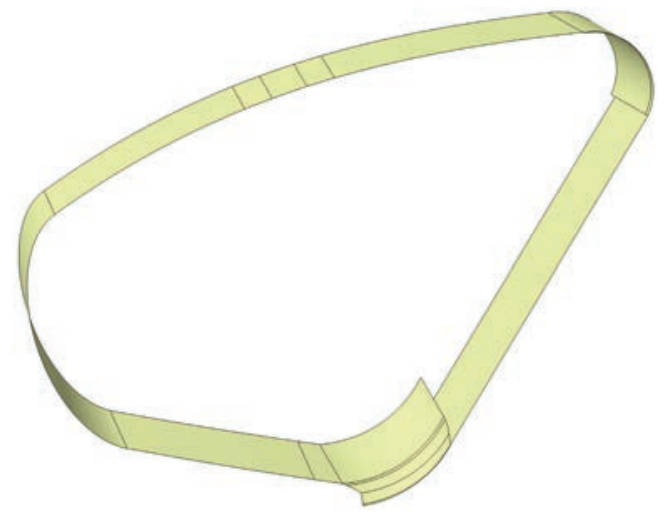

Fig. 11. A surface of the bumper with a separated area being the immediate vicinity of the reflex lamp: a) A surface of the bumper, b) separated area

Rys. 11. Powierzchni $A$ zderzaka z wyodrębnionym rejonem będącym bezpośrednim otoczeniem odblasku: a) powierzchnia $A$ zderza$\mathrm{ka}$, b) wyodrębniony rejon 
Podstawową bryłę obudowy utworzoną na podstawie danych wejściowych przedstawiono na rys. 10 .

0 ile główny kształt obudowy jest determinowany przez geometrię soczewki zewnętrznej, a co za tym idzie - powierzchnię $A$ będącą daną wejściową pochodzącą od dostawcy, tak dopasowanie odblasku do reszty złożenia (tu: zderzaka samochodowego) leży w gestii konstruktora. Przemyślane unieruchomienie elementu pozwala na dokładne dopasowanie go do złożenia i - jak w tym przypadku - utrzymanie wymaganej szczeliny między odblaskiem a zderzakiem. Aby spełnić wymagania dotyczące stałej szerokości szczeliny, do struktury obudowy powinna być wprowadzona jeszcze jedna dana wejściowa - powierzchnia $A$ zderzaka. Ściślej: potrzebny jest rejon będący w bezpośrednim otoczeniu odblasku (rys. 11).

$\mathrm{Na}$ bazie wymienionych danych wejściowych konstruktor jest w stanie utworzyć podstawową bryłę obudowy, a także spełnić wymagania dotyczące zachowania odpowiedniej odległości między zderzakiem a odblaskiem (rys. 12). Do utrzymania zadanej odle-

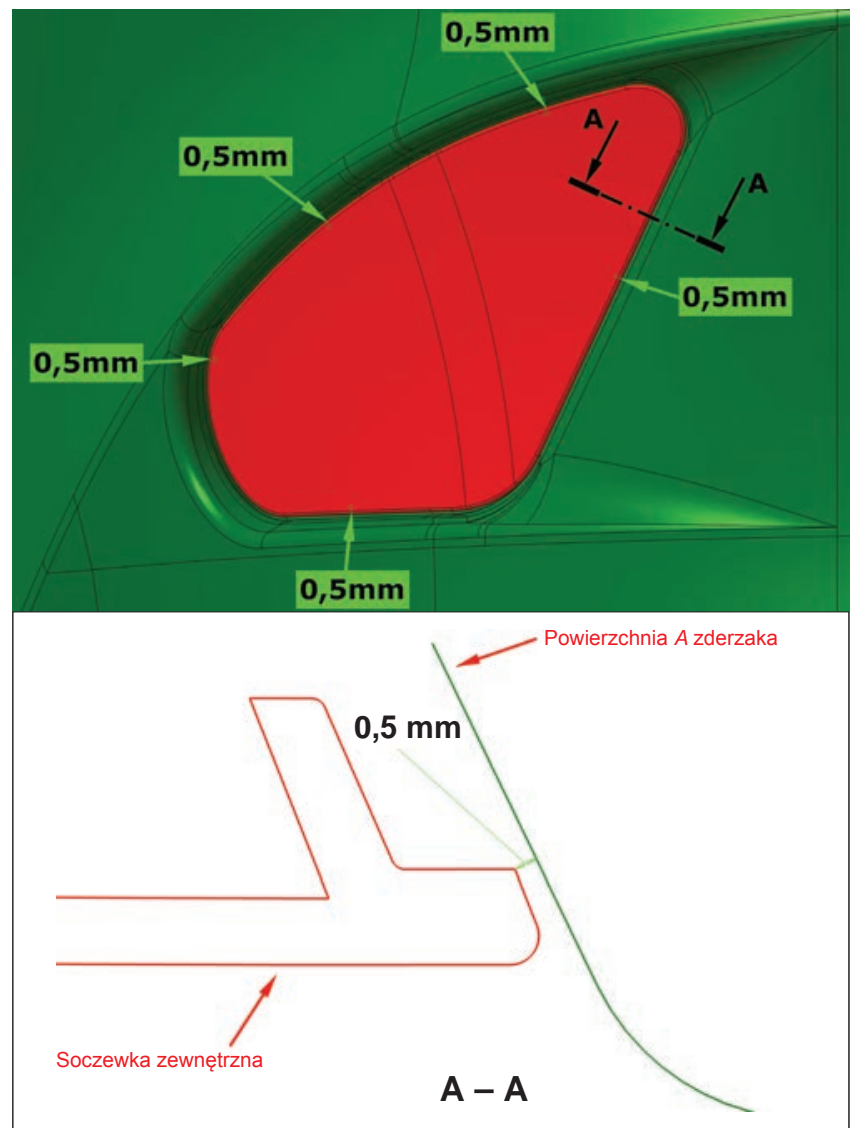

Fig. 12. The required distance between the reflex lamp and the bumper

Rys. 12. Wymagany dystans między odblaskiem a zderzakiem

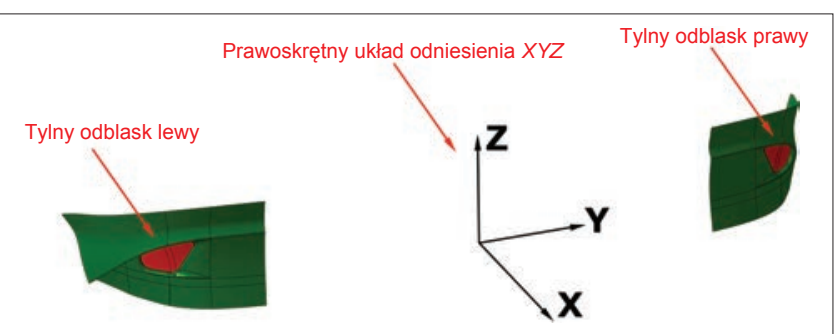

Fig. 13. Right-handed $X Y Z$ reference system Rys. 13. Prawoskrętny układ odniesienia $X Y Z$ głości służą w tym przypadku żebra wokół zewnętrznej powierzchni obudowy. Ze względu na tolerancje technologiczne obu elementów (zderzaka i odblasku) żebra te nie wchodzą w bezpośredni kontakt ze zderzakiem, lecz zachowują minimalny dystans. Przyjmując prawoskrętny układ odniesienia $X Y Z$ (rys. 13) w taki sposób, że zwrot osi $X$ jest skierowany do tyłu samochodu i przebiega wzdłuż płaszczyzny symetrii samochodu, a zwrot osi $Z$ jest skierowany do góry samochodu, konstruktor ustala utworzonymi żebrami odblask wzdłuż osi $Y$ i $Z$ (rys. 14).

Na następnym etapie projektowania odblasku dodawane są pozostałe elementy konstrukcyjne, takie jak klipsy mocujące, piny ustalające, rejon odpowietrzający czy lokalne technologiczne pocienienie materiału (rys. 15). Te elementy stanowią propozycję konstruktora, która później może być modyfikowana i optymalizowana. Ważne - z punktu widzenia ustalenia i samego unieruchomienia odblasku
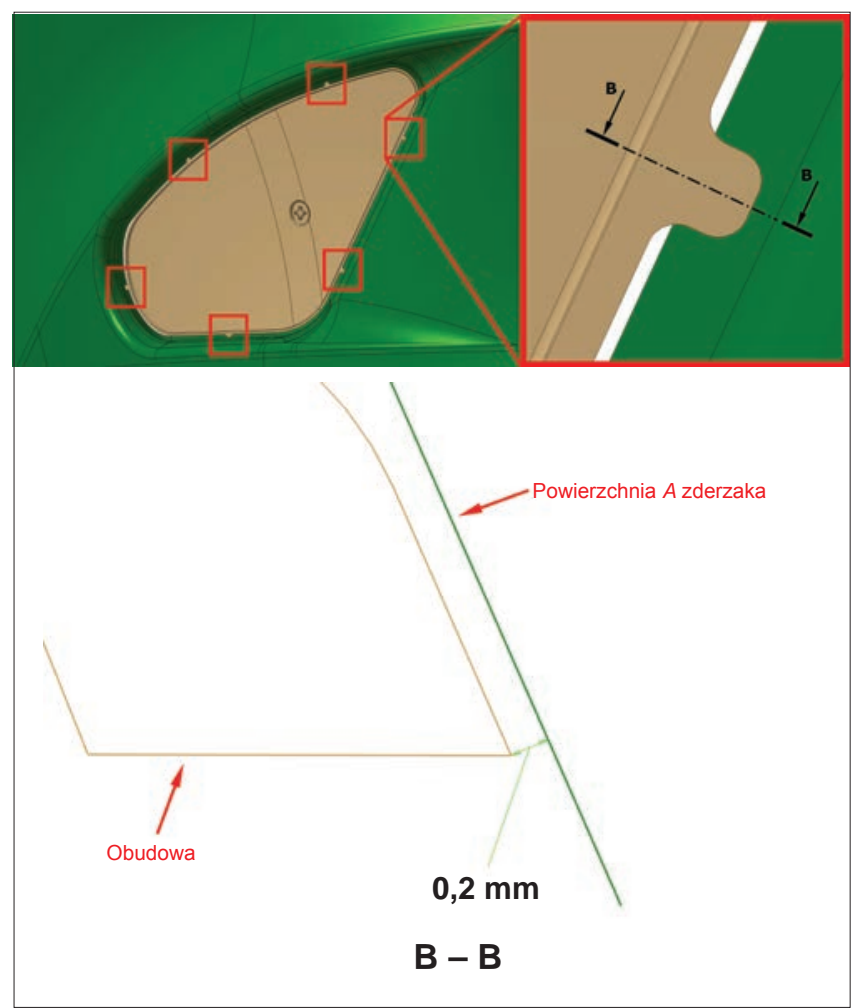

Fig. 14. Ribs on the housing ensuring the desired distance along the $Y$ and $Z$ axes

Rys. 14. Żebra na obudowie zapewniające pożądany dystans wzdłuż osi $Y$ i $Z$

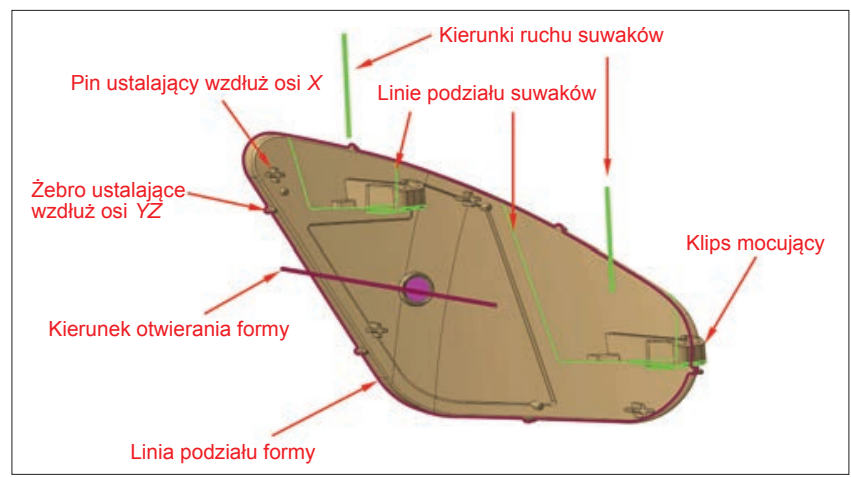

Fig. 15. The finished housing model Rys. 15. Ukończony model obudowy 


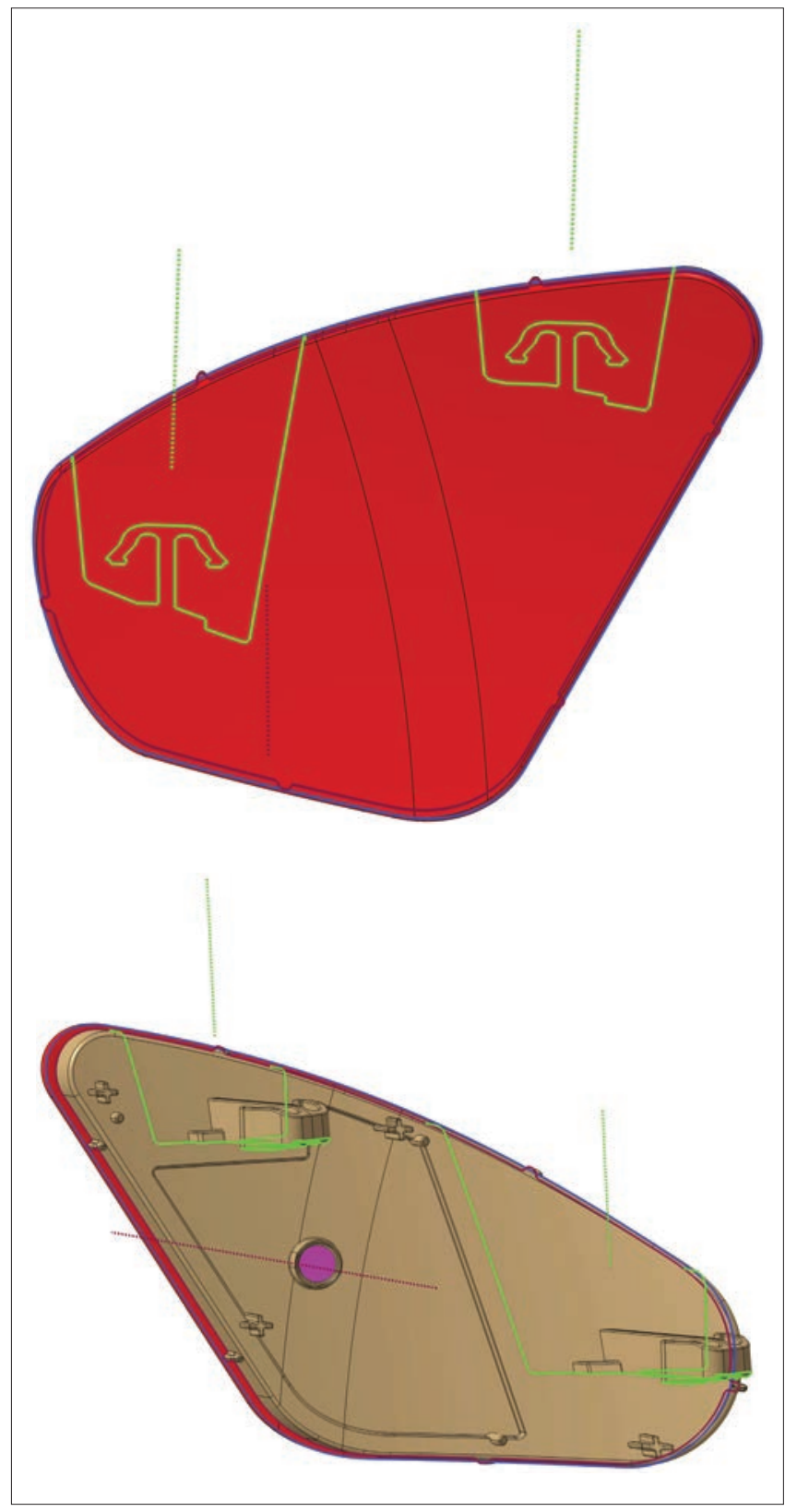

Fig. 16. The finished rear car reflex lamp with marked line of dividing the mold (for each element), lines of dividing the sliders and the direction of opening the mold (for each element) and directions of movement of the sliders

Rys. 16. Ukończony odblask tylny z zaznaczoną linią podziału formy (dla każdego elementu), liniami podziału suwaków oraz kierunkiem otwierania formy (dla każdego elementu) i kierunkami ruchu suwaków

wzdłuż osi $X$ - są klipsy i piny ustalające. Konstruktor podczas tworzenia struktury tych i pozostałych rejonów postaci geometrycznej odblasku powinien przewidzieć scenariusze przyszłych zmian. Oczywiście nie jest możliwe, aby utworzona struktura obejmowała wszystkie potencjalne zmiany, jednak margines konfigurowalności powinien być jak najszerszy.

Po przygotowaniu geometrycznych postaci soczewki zewnętrznej i obudowy konstruktor dodaje do modeli 3D przebieg linii podziału formy i linii podziału suwaków oraz zaznacza kierunek otwierania formy i kierunki ruchu suwaków (rys. 16). Nie znaczy to jednak, że elementy te są tworzone dopiero po ukończeniu modeli 3D. Ich planowanie oraz przewidywanie

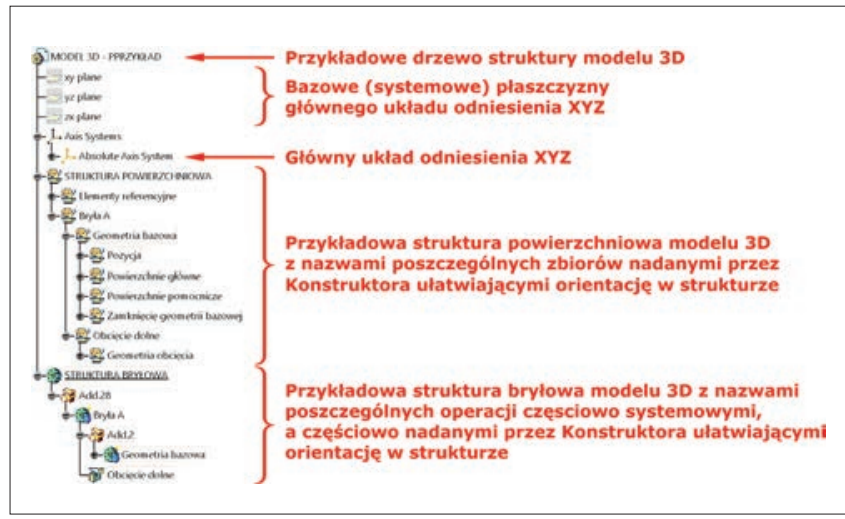

Fig. 17. An example of the content of the 3D model structure tree Rys. 17. Przykładowa zawartość drzewa struktury modelu 3D

są kluczowe i obecne na każdym etapie procesu projektowania.

Wraz ze wzrostem skomplikowania postaci geometrycznej modelu projektowanego elementu szczególnie ważną rolę zaczyna odgrywać zawartość drzewa struktury modelu, która w istocie tworzy sam model 3D, a więc jej optymalizacja jest najważniejsza w całym procesie powstawania modelu 3D. Co prawda możliwe są sytuacje, w których zawartość drzewa jest tworzona automatycznie podczas tworzenia modelu 3D, bez ingerencji użytkownika, jednak tylko pełna kontrola nad tą zawartością umożliwia osiągnięcie optymalnego rezultatu.

Ponieważ w systemach klasy CAx są dwa typy reprezentowania modeli 3D - powierzchniowe i bryłowe - zawartość drzewa może uwzględniać oba i wyodrębniać jedne od drugich. W rezultacie konstruktor otrzymuje dwie struktury - powierzchniową i bryłową, przy czym struktura powierzchniowa powinna być bazą dla struktury bryłowej (rys. 17). Organizacja struktury, w tym nazewnictwo poszczególnych zbiorów operacji, zależy od konstruktora i ma istotny wpływ na proces optymalizacji tworzenia modelu 3D (co będzie szerzej opisane w drugiej części artykułu). Dopuszczalna jest również zmiana nazw domyślnych (systemowych) poszczególnych operacji, o ile nie wpływa ona w negatywny sposób na proces optymalizacji modelu 3D.

\section{LITERATURA}

[1] Wilczyński K. [red.] „Przetwórstwo tworzyw sztucznych”. Warszawa: Oficyna Wydawnicza Politechniki Warszawskiej, 2000.

[2] Zawistowski H., Frenkler D. „Konstrukcja form wtryskowych do tworzyw termoplastycznych" Warszawa: Wydawnictwo Naukowo-Techniczne, 1984.

[3] Jasiulek P. „Łaczenie tworzyw sztucznych metodami spawania, zgrzewania, klejenia i laminowania” Krosno: Wydawnictwo i Handel Książkami „KaBe” s.c., 2014. 